\title{
Systemic infection in Atlantic salmon Salmo salar with a Dermocystidium-like species
}

\author{
R. P. Hedrick ${ }^{1}$, C.S. Friedman ${ }^{2}$, J. Modin ${ }^{2}$ \\ ${ }^{1}$ Department of Medicine, School of Veterinary Medicine, University of California, Davis, California 95616, USA \\ ${ }^{2}$ California Department of Fish and Game, Fish Disease Laboratory, Rancho Cordova, California 95760, USA
}

\begin{abstract}
A chronic mortality in subadult Atlantic salmon Salmo salar reared in California was caused by systemic infections with a Dermocystidium-like species. Parasitic cells occurred primarily at the periphery of granulomas in the kidney, liver, spleen and testes. Actively replicating vegetative stages 2 to $7 \mu \mathrm{m}$ in diameter were also found within melanomacrophages of the kidney. These stages contained a dense granular cytoplasm with osmiophilic inclusions, a nucleus with an indistinct nucleolus and were surrounded by thick, Periodic-Acid-Schiff-positive cell walls. The parasite induces a similar disease and has structural affinities to Dermocystidium spp. described as causes of systemic infections in salmonids in Europe.
\end{abstract}

\section{INTRODUCTION}

Dermocystidium spp. have been associated with infections in oysters, certain amphibians, eels and frequently as the cause of adult and fry mortality of Pacific salmon (Mackin et al. 1950, Reichenbach-Klinke \& Elkan 1965, Pauley 1967, Allen et al. 1968, Perkins 1969, Wooten \& McVicar 1982, Molnár \& Sövényi 1984). Infections in fish are generally cutaneous, often involving the gills and can cause mortality when parasites are in large numbers.

Although less frequentiy reported than skin and gill infections, systemic infections with Dermocystidium spp. are known and may be associated with mortality as shown in Atlantic salmon Salmo salar in Scotland (McVicar \& Wooten 1980), rainbow trout Oncorhynchus mykiss in France (Moer et al. 1986) and brown trout Salmo trutta and Atlantic salmon in Ireland (Nash et al. 1989).

Systemic Dermocystidium infections are characterized as chronic and may or may not involve a strong host immune response. McVicar \& Wooten (1980) found a Dermocystidium sp. associated with visceral infections in Atlantic salmon parr from Scotland. The fish had swollen abdomens, apparently a result of extensive caseous lesions most prominent in the visceral fat (McVicar \& Wooten 1980). They reported a minimal host response to the vegetative stages of the parasite. A second case of systemic parasitism of sal- monid fish by a new species, D. macrophagi sp. n., was reported by Moer et al. (1986) in rainbow trout from France. Initial observations of the gross kidney lesions in these trout closely resembled those associated with parasitism by the PKX myxosporean (most likely a Sphaerospora sp.), the causative agent of proliferative kidney disease, PKD (Kent \& Hedrick 1986, Hedrick et al. 1988). Most recently, Nash et al. (1989) have found systemic infections with a Dermocystidium sp. in brown trout and Atlantic salmon in Ireland and rainbow trout from France. In the rainbow trout they also found concurrent infections with PKX.

In the following report we describe similar infections in farmed Atlantic salmon from the west coast of the USA. The disease induced by the Dermocystidium-like agent in our study caused a chronic but steady mortality in the population.

\section{MATERIALS AND METHODS}

Fish. Subadult Atlantic salmon examined in this study were received as eyed eggs from Finland. The fish were reared at a private farm in Northern California supplied by spring water. During one short episode however, water from a small adjacent creek was used. The fish were maintained in plastic swimming poollike tanks with a diameter of $8 \mathrm{~m}$ without abnormal losses from fry to an age of $2 \mathrm{yr}$. The grower contacted 
our laboratory after a chronic mortality began that was exacerbated by sorting of the fish or cleaning of the tanks.

Light microscopy. Portions of the kidney, spleen, liver, intestine, testes or ovary, gill and heart were placed into Davidson's fixative (Humason 1979). After $16 \mathrm{~h}$ of fixation, the samples were transferred to $70 \%$ ethanol and processed for standard paraffin embedding and sectioning. Tissue sections $(5 \mu \mathrm{m})$ were stained with hematoxylin and eosin or Periodic Acid Schiff (PAS) reagents. Imprints made directly from infected tissues were air-dried for $30 \mathrm{~min}$, fixed in $100 \%$ methanol for 5 min and stained with LieshmanGiemsa.

Electron microscopy. Samples from the kidney, spieen and liver of infected fishes were placed into $2.5 \%$ glutaraldehyde in $0.1 \mathrm{M}$ cacodylate buffer $(\mathrm{pH}$ 7.4) and fixed for $24 \mathrm{~h}$ at $4{ }^{\circ} \mathrm{C}$. The tissues were rinsed twice in buffer and then post-fixed in $1 \%$ aqueous $\mathrm{OsO}_{4}$, dehydrated through a graded ethanol series, infiltrated and embedded in Spurr's low viscosity medium. Thin sections (10 to $20 \mathrm{~nm}$ ) were stained with uranyl acetate and lead citrate prior to examination with a Phillips EM 400 electron microscope at $75 \mathrm{kV}$.

\section{RESULTS}

\section{Gross signs}

External gross signs among moribund fish were unremarkable with the exception that certain fish with advanced infections were slightly emaciated. Upon internal examination, widely disseminated nodules were found in the kidney, spleen, liver and gonads. In the kidney of several fish the nodules coalesced giving the organ a mottled and swollen appearance. A random sample from the population of 500 salmon showed $15 / 20$ exhibiting some gross internal. sign of infection.

\section{Light microscopy}

Microscope examination of stained tissue sections of the affected organs revealed a variable host response. Splenic and hepatic lesions were primarily characterized by well-circumscribed granulomas (Fig. $1 \mathrm{~A}$ ). Macrophages containing numerous parasites were most abundant at the periphery of these lesions (Fig. 1B). The granulomas were circumscribed by multiple layers of macrophages and fibroblastic cells (Fig. 1B). There was often a more diffuse granulomatous response in the kidney, spleen (Fig 1C), and testes (not shown). Numerous parasites also occurred within macrophages throughout the lesion (Fig. 1D).
Small parasitic cells ranging in diameter from 2 to 7 um were found principally within macrophages, but released forms were also detected in both stained tissue sections (Fig. 1E) and imprints (Fig. 1F). The cell walls of the parasites stained positively with PAS. Although there was involvement of the hematopoietic tissues, the fish did not appear anemic, as evidenced by an absence of pallor of the gills and blood.

\section{Electron microscopy}

The parasites were found primarily within melaninbearing macrophages (Fig. 2A). One to several parasites could be found within the host cell. The outer wall of tho parasites had a fibrogranular appearance (Fig. 2B). This layer surrounded a thick (45 nm) underlying electron-lucent cell wall which in dividing stages formed the partitions between developing daughter cells (Fig. 2B). Internally, the parasitic cells contained a coarse, dense cytoplasm with numerous ribosomes (Fig. 3). Several mitochondria were found in some but not all cells. Vacuoles, sometimes containing concentric structured bodies, up to diameters of $700 \mathrm{~nm}$ were also common in the cytoplasm (Fig.3). Electron-dense bodies, also found in the cytoplasm, varying in shape from spherical to rod-like, were also found in each parasite.

\section{DISCUSSION}

Dermocystidium spp, have been known to be the cause of gill and skin infections in fish but only recently have they appeared as causes of systemic disease. At least 3 previous reports have documented systemic infections in European salmonids (McVicar \& Wooten 1980, Moer et al. 1986, Nash et al. 1989). The diseases reported in each case had certain similarities and some distinct differences. They were characterized as slowly progressing chronic infections of the viscera or visceral organs. McVicar \& Wooten (1980) found nodular growths with numerous parasites at the periphery and a necrotic center in affected Atlantic salmon parr. There was little host response and only a few macrophages in affected tissues. A greater host cell response, including numerous macrophages, was detected in the lesions found in the Atlantic salmon in our study and the rainbow trout examined by Moer et al. (1986). The presence of numerous macrophages in. the lesions and their intracellular parasitism with the agent prompted Moer et al. (1986) to name the parasite they examined Dermocystidium macrophagi $\mathrm{n}$. sp.

The parasite observed in our study was associated with a chronic loss of 2 yr Atlantic salmon. The farm 

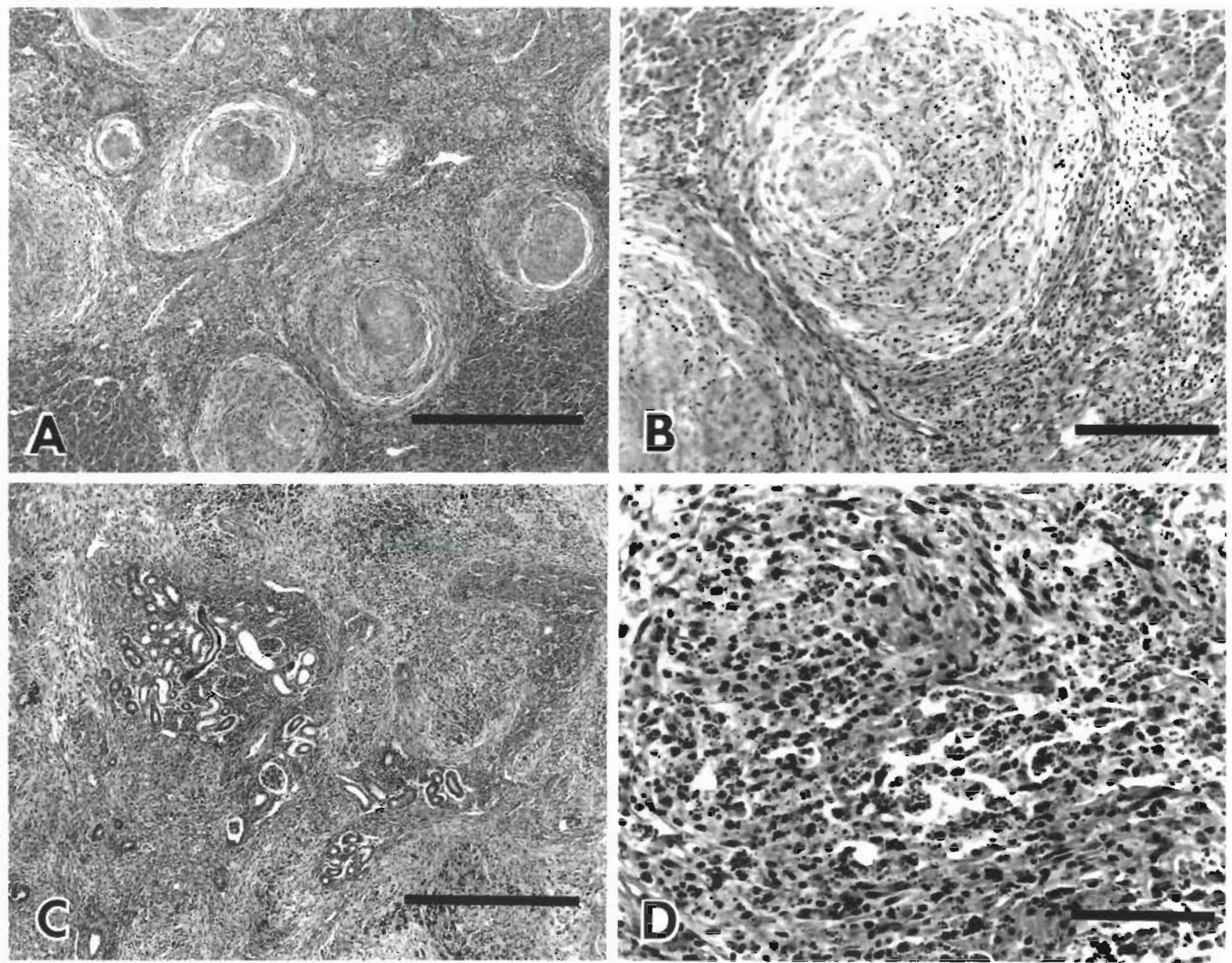

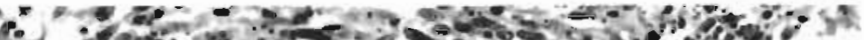

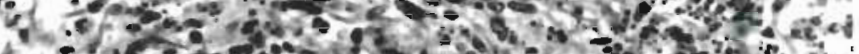

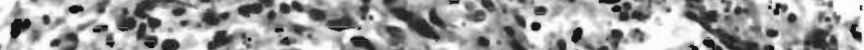

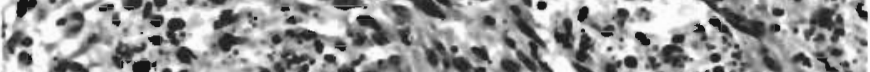

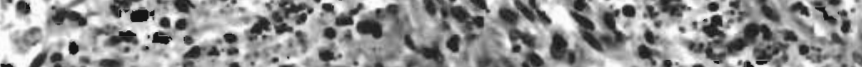

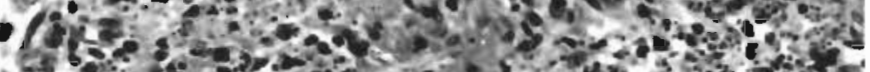

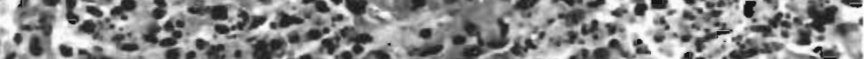

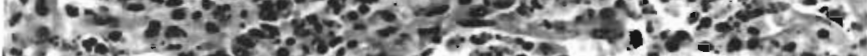

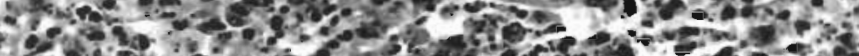

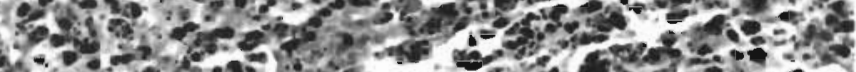

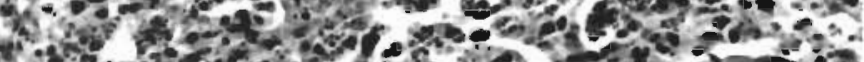

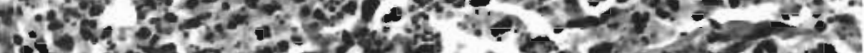

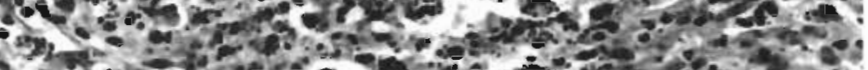

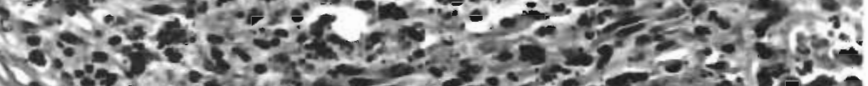

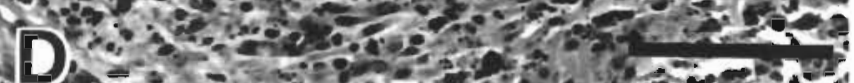

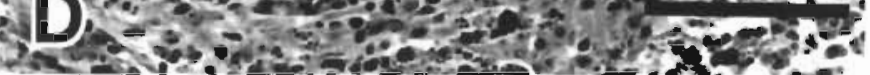
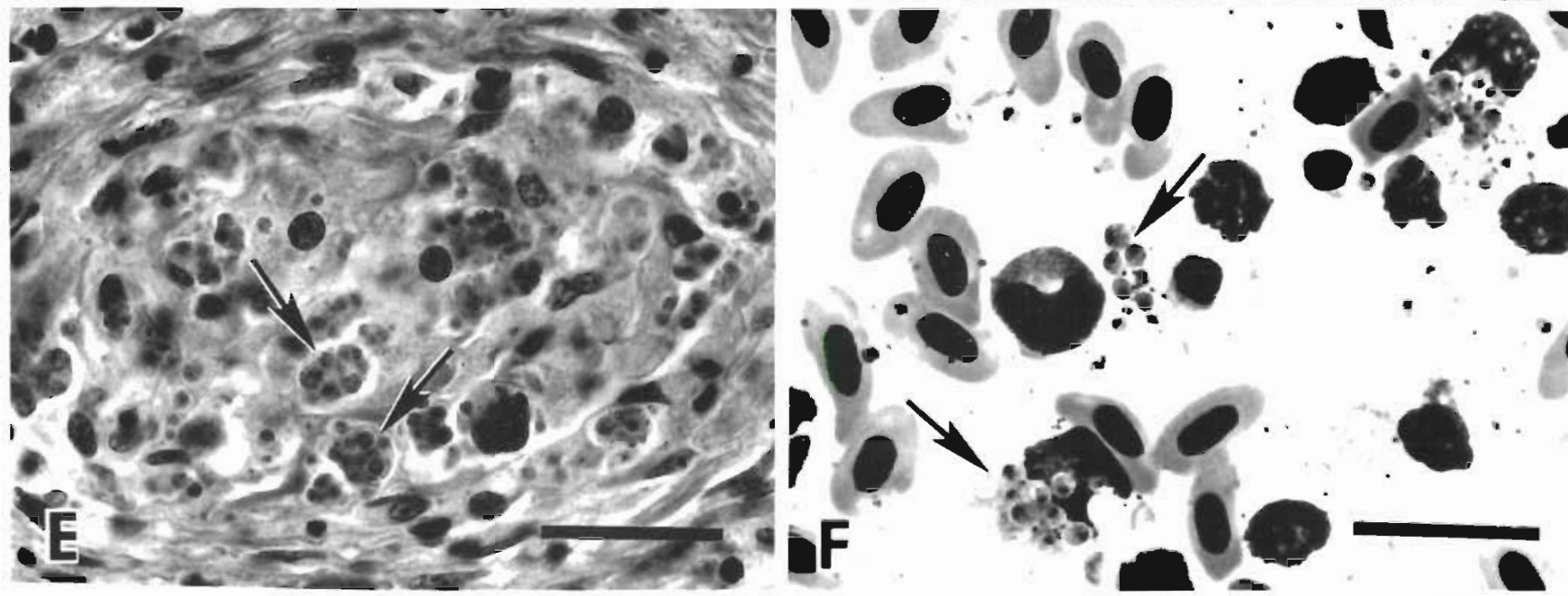

Fig. 1. Salmo salar. Hematoxylin-stained tissue sections from fish infected with Dermocystidium-like species. (A, B) Nodular lesions in liver. Bars $=4 \mathrm{~mm}$ and $2 \mathrm{~mm}$ respectively. (C) Dissemination of parasites in the kidney. Bar $=4 \mathrm{~mm}$. (D) Massive numbers of intracellular protozoans in the kidney lesions. Bar $=0.5 \mathrm{~mm}$. (E) Arrows indicate macrophages containing vegetative stages of the parasite found in the kidney. Bar $=33 \mu \mathrm{m}$. (F) Lieshman-Giesmsa stained imprints from the kidney with macrophages containing parasites (arrows). Bar $=33 \mu \mathrm{m}$ 


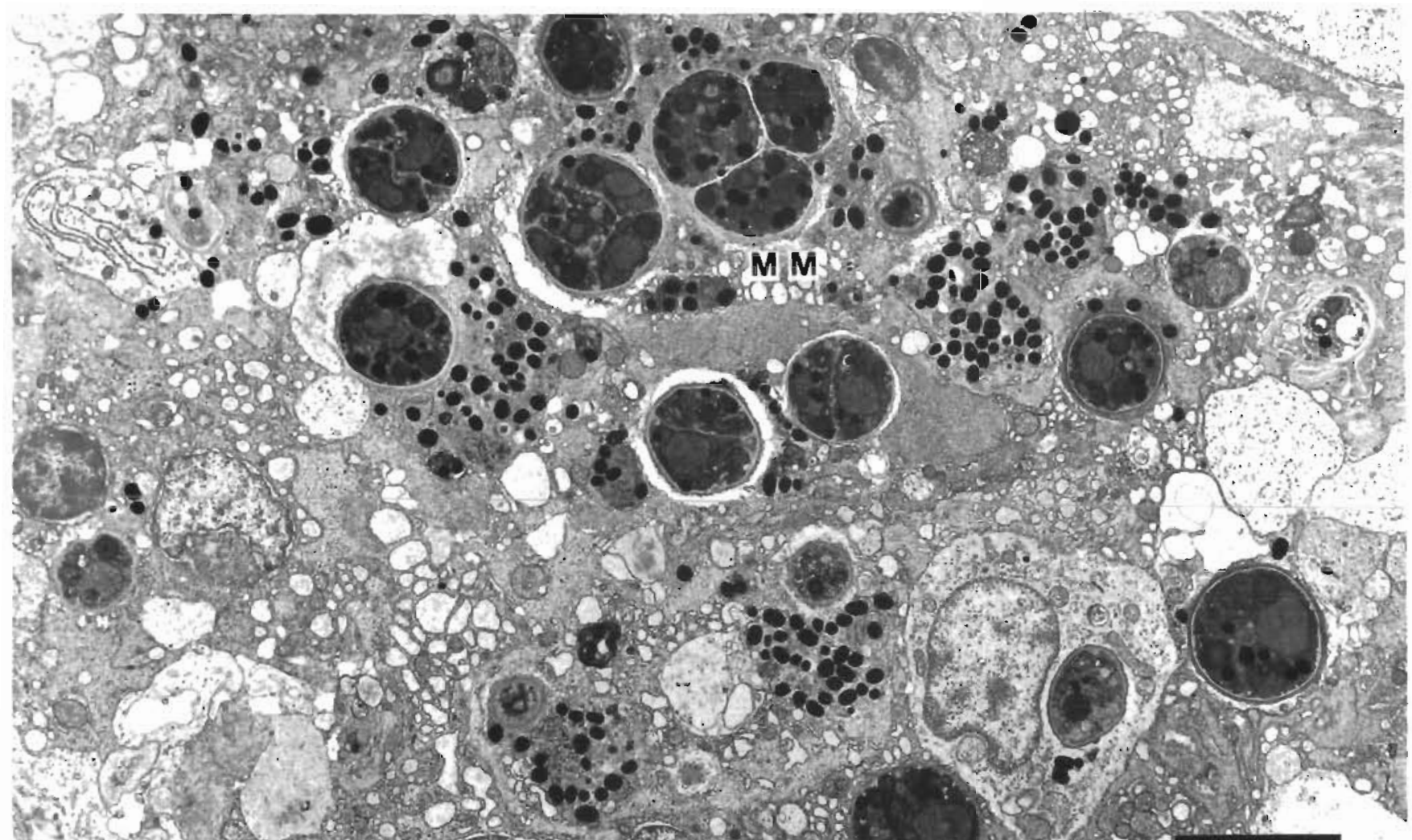

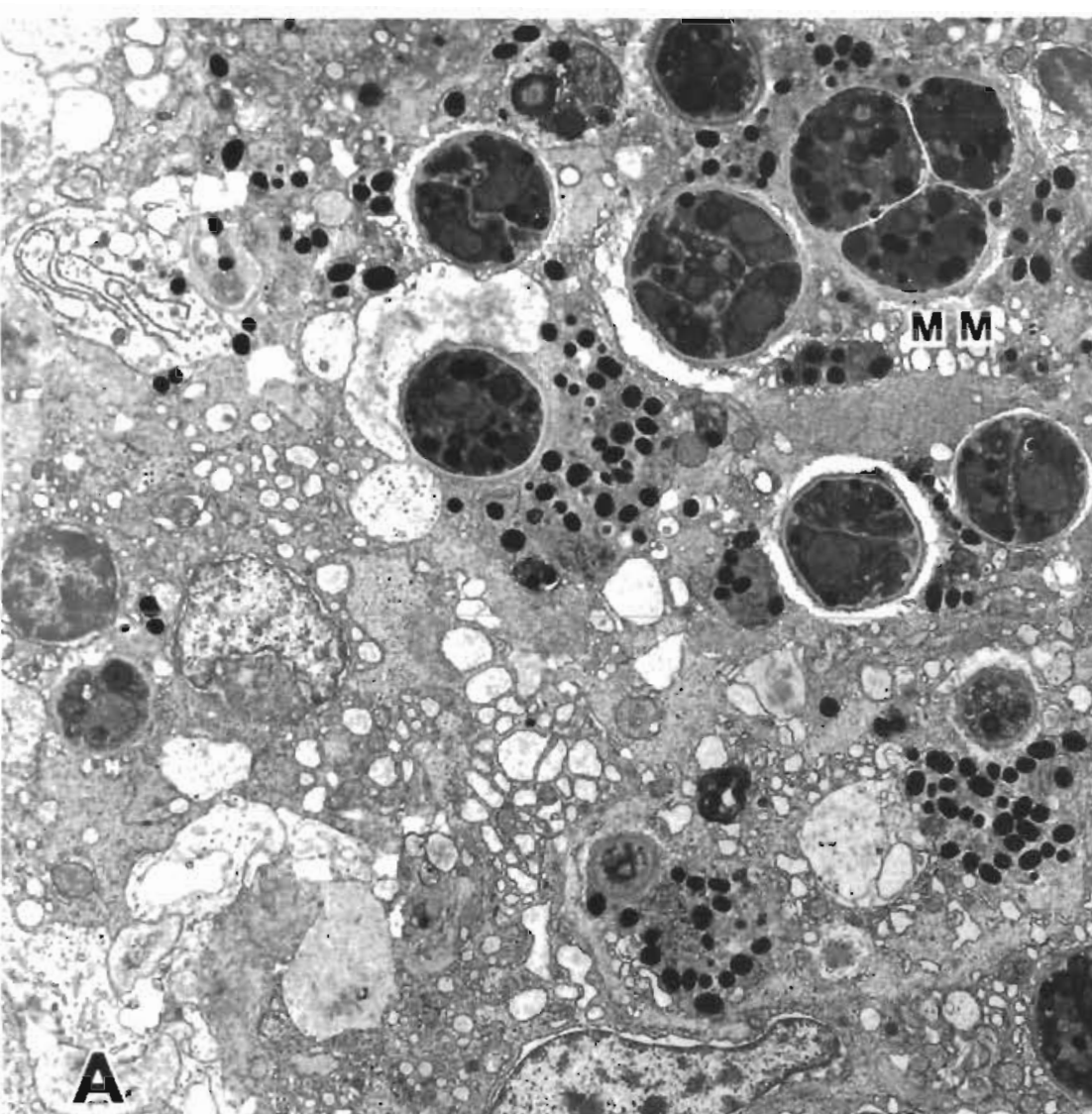

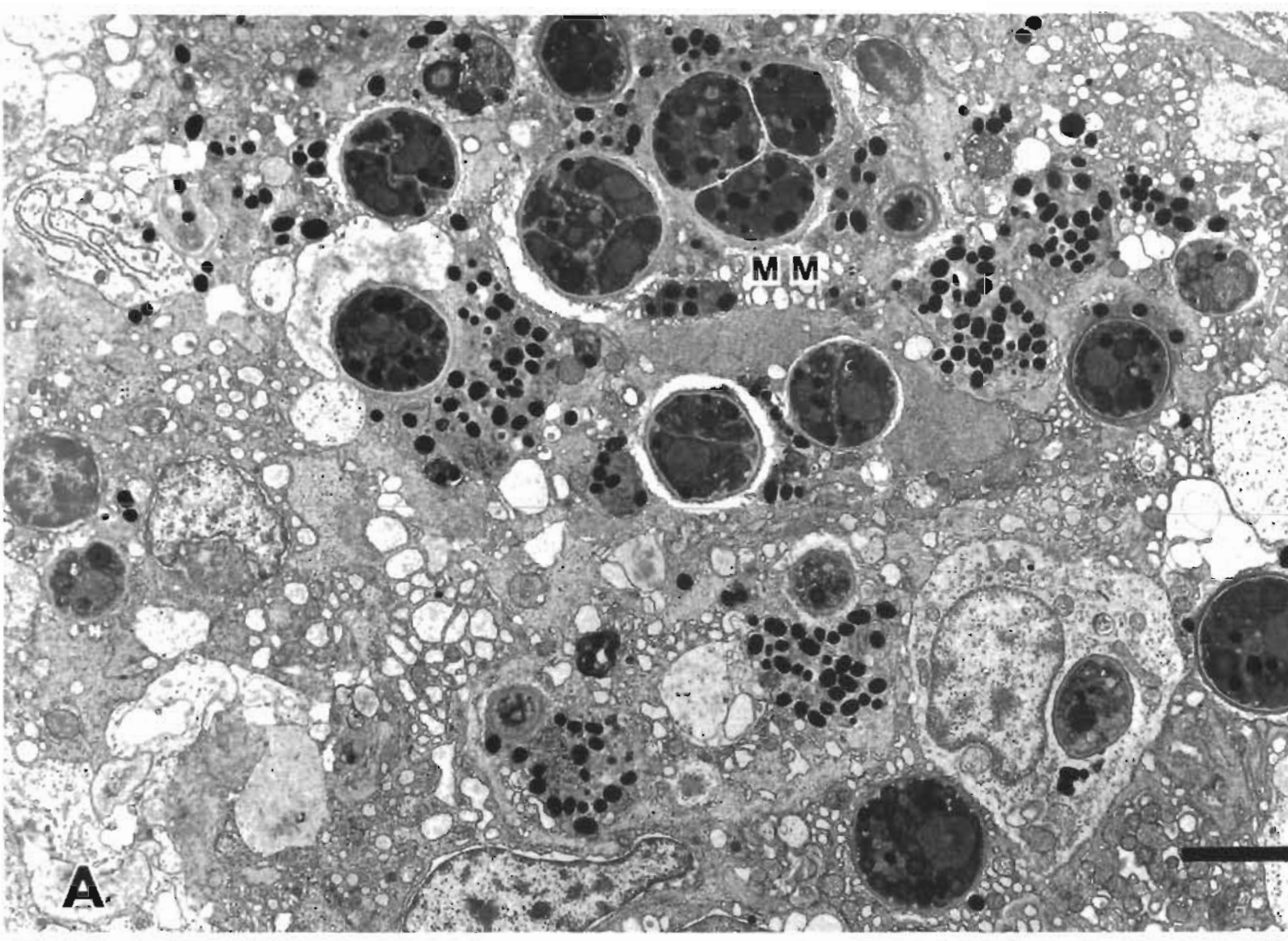
$302600-695$

\section{急}
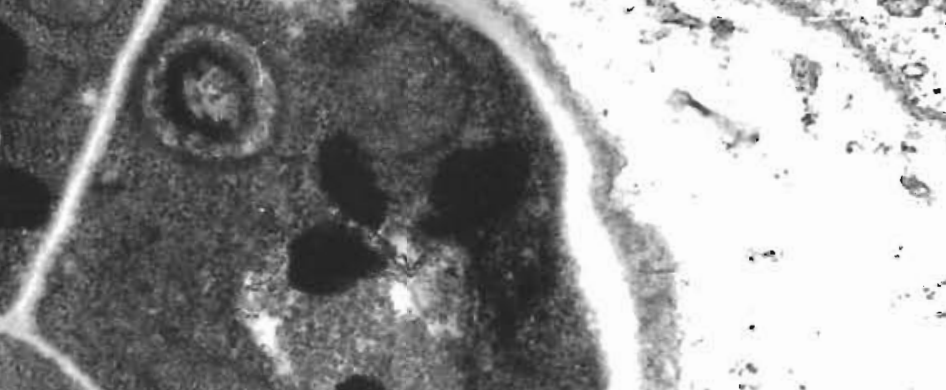
owner routinely conducted gross internal examinations of dead fish collected from the tank and indicated that nearly all exhibited the signs of the disease. The gross lesions he described and those seen in certain fish from our random sample resemble somewhat infections caused by Renibacterium salmoninarum (Sanders \& Fryer 1980, Bruno 1986) and the PKX myxosporean (Ferguson \& Needham 1978).

At least 2 types of microscopic lesions were observed in the Atlantic salmon in our study. The nodular form of the disease with distinct granulomas may be characteristic of fish more effectively containing the infection. In contrast, widely disseminated infections with less host cell response were also detected (Fig. 1C, D). We are assuming that intracellular parasitism results in death of the host cell based on the poor condition of these host cells as seen in paraffin section, imprints and electron micrographs.

The ultrastructural characteristics of the parasite observed in the Atlantic salmon in our study closely resembles those previously reported for systemic Dermocystidium infections, best described by Moer et al. (1986). The thickened cell wall coated by a fibrogranular layer perhaps of host cell origin (Moer et al. 1986), dense ribosome laden cytoplasm, numerous mitochondria, electron-dense inclusions and concentric bodies and vacuoles were consistent features of all the previously reported parasites and those in our study (Figs. 2 and 3). Prominent vacuole development, giving the parasite a 'signet-ring' appearance, as reported for other Dermocystidium spp., was not found in our study.

The source of the parasite found in our study is unknown. This is the first recorded episode of a systemic infection due to a Dermocystidium-like species in freshwater-reared salmonids outside of Europe of which we are aware. We presume the infection was not introduced with the eggs but instead originated from the use of creek water during a short episode of rearing of the Atlantic salmon.

Dermocystidium is commonly encountered in Pacific salmon in coastal streams of the western USA but in these cases it is found forming macroscopically observed cysts in the gills (Rich Holt, Oregon Department of Fish and Wildlife, USA, pers. comm.). An agent with some similarities to the parasite observed in our study has been reported as the cause of a systemic infection in chinook salmon Oncorhynchus tshawytscha in sea water pens from Washington state, USA (Elston et al. 1986, Harrell et al. 1986). The gross pathology, intracellular parasitism in macrophages and ultrastructural similarities of the parasite they described as the 'rosette agent' to the systemic Dermocystidium infections are remarkable. The rosette agent however, was found in fish in seawater and the microscopic pathology was characterized by a minimal inflammatory response with some necrosis and edema. Whether these differences in the host responses to the rosette agent in chinook and Dermocystidium in the Atlantic salmon are host-dependent or due to distinctly different parasites is unknown.

Current attempts are underway to transmit the parasite to juvenile rainbow trout and Pacific salmon and to culture the organism in thioglycollate broth, salmonid cell lines and freshly isolated macrophages from healthy trout. Further comparative studies on the characteristics of these systemic agents and their potential relationship to Dermocystidium spp. associated with infections of the gills and skin are warranted. This should provide insights into the nature of the respective parasites.

Acknowledgements. This work was supported in part by Dingell-Johnson/Wallop-Breaux Fish Restoration Act funds administered through the California Department of Fish and Game. The cooperation of the California Department of Fish and Game and Mr Fritz Sniedman were greatly appreciated. The suggestions of Drs J.M. Groff, D.E. Hinton and R.A. Elston helped to improve the manuscript. Thanks to the histotechnicians of the Veterinary Medicine Teaching Hospital for their preparations of stained tissue sections for light microscopy and Mr R. Munn for his electron microscopy expertise.

\section{LITERATURE CITED}

Allen, R. L., Meekin, T.K., Pauley, G. B., Fujihara, M.P. (1968). Mortality among chinook salmon associated with the fungus Dermocystidium. J. Fish. Res. Bd Can. 25: $2467-2475$

Bruno, D. W. (1986). Histopathology of bacterial kidney disease in laboratory infected rainbow trout, Salmo gairdneri Richardson, and Atlantic salmon, Salmo salar L., with reference to naturally infected fish. J. Fish Dis. 9: 523-537

Elston, R. A., Harrell, L., Wilkinson, M. T. (1986). Isolation and in vitro characteristics of chinook salmon (Oncorhynchus tshawytscha) rosette agent. Aquaculture 56: 1-21

Ferguson, H.W., Needham, E. A. (1978). Proliferative kidney disease in rainbow trout Salmo gairdneri Richardson. J. Fish Dis. 1: 91-108

Harrell, L. W., Elston, R. A., Scott, T.M., Wilkinson, M.T. (1986). A significant new systemic disease of net-pen

Fig. 2. Salmo salar. Electron micrographs of Dermocystidium-like species infections in the kidney. (A) The parasites are found principally within melanomacrophages $(M M)$. Bar $=5 \mu \mathrm{m}$. (B) Parasites undergoing division by internal cleavage with the development of new plasmalemma (PL) and cell walls. The nucleus (N) was found eccentrically located and the cytoplasm had occasional mitochondria $(\mathrm{M})$. Bar $=0.5 \mu \mathrm{m}$ 


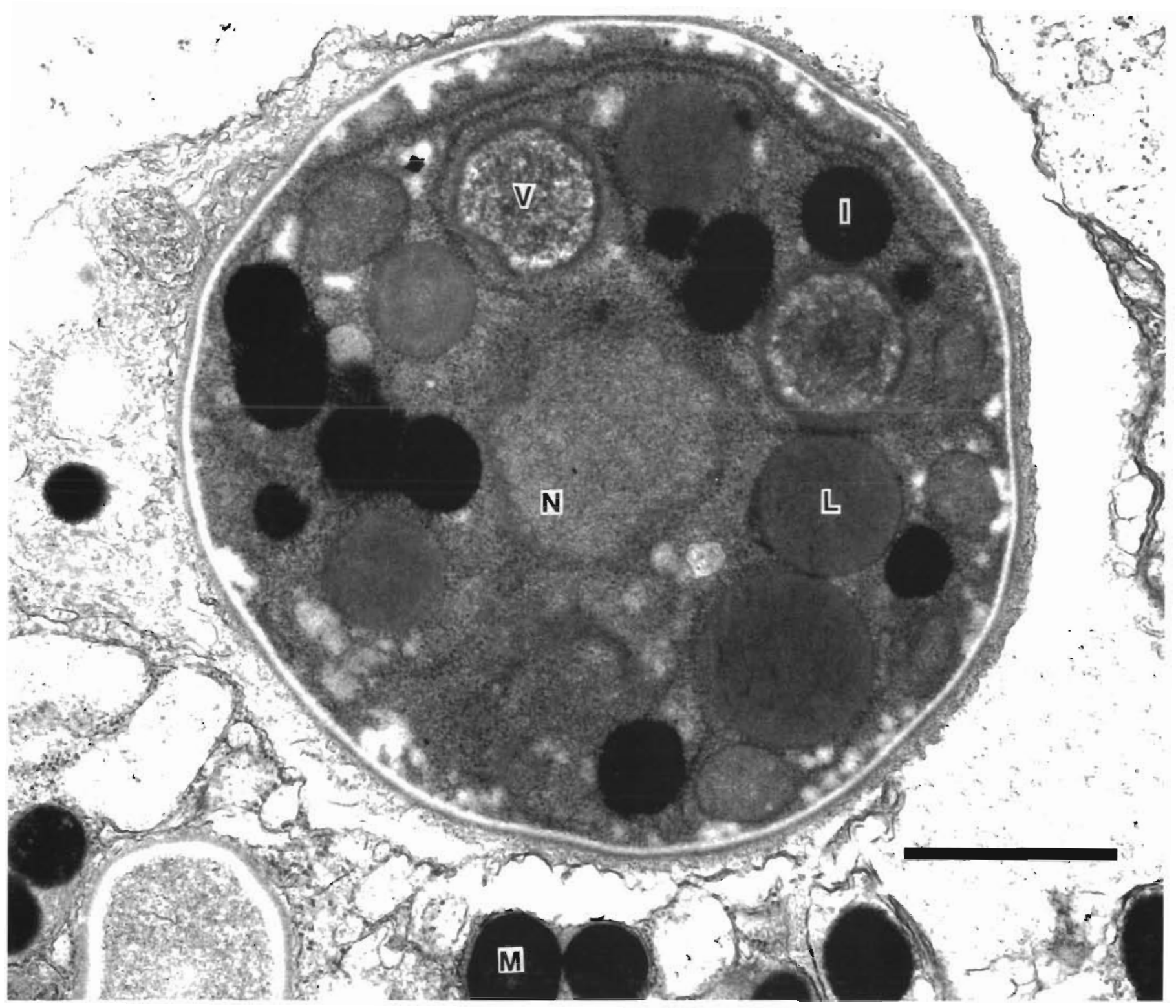

Fig. 3 Salmo salar Electron micrograph of Dermocystidium-like species in the kidney. The chromatin in the nucleus (N) is homogeneous and there is no distunct endosome. Vacuoles (V), electron-dense inclusions (I) and lipid droplets (L) in the cytoplasm of the parasite. Melanin granules $(M)$ of a melanomacrophage. Bar. $=1 \mu \mathrm{m}$

reared chinook salmon (Oncorhynchus tshawytscha) Aquaculture $55 \quad 249-262$

Hedrıck, R. P, Kent, M. L., Toth, R J, Morrison, J. K. (1988) Fish infected with Sphaerospord spp. Thélohan (Myxosporea) from waters enzootic tor proliferative kidney disease of salmonids. J. Protozool 35: 13-18

Humason, G. L. (1979). Animal tissue techniques. W. H. Freeman. San. Francisco

Kent, M. L., Hedrick, R. P. (1985). PKX, the causative aggent of proliferative kidney disease (PKD) in Pacific salmonid fishes and its affinities with the Myxozoa J Protozool 32: $254-260$

Mackin, J. G., Owen, H, Collıer, A (1950) Preliminary note on the occurrence of a new protistan parasite, Dermocys- tidium marmum n sp. in Crassostrea gigas (Gmelin). Science $111 \quad 328-329$

McVicar, A H. Wooten, R. (1980). Disease in farmed juvenile Atlantic salmon caused by Dermocystıdium sp. In: Abne, W. (ed.) Fish diseases. Third COPRAQ-Session, SpringerVerlag, Berlin, p. 165-173

Moer, A, Manier, J.-F., Bouix, G. (1986). Etude ultrastructural de Dermocystidium macrophagi n. sp., parasite intracellular de Salmo gairdneri Richardson, 1836. Annls Sci. nat. (ser. Zool.) 8: 143-151

Molnár, K. Sövényi. J.F. (1984). Dermocystidium anguillae infection in elvers cultured in Hungary. Aqula. Hung. 4: $71-78$

Nash, G., Southgate, P., Richards, R. H. (1989). A systemic 
protozoal disease of cultured salmonids. J. Fish Dis. 12: $157-173$

Pauley, G. B. (1967). Prespawning adult salmon mortality associated with a fungus of the genus Dernocystidium J. Fish. Res. Bd Can. 24: 843-848

Perkins, F. O. (1969). Ultrastructure of vegetative stages in Labyruthomyxa marinum (= Dermocystidium marinum), a commercially significant oyster pathogen. J. Invert. Pathol. 13: 199-222

Responsible Subject Editor: Dr 1. Paperna, Rehovot, Israel
Reichenbach-Klinke, H., Eldan, E. (1965). The principal diseases of lower vertebrates. Academic Press, London

Sanders, J. E., Fryer, J. L. (1980). Renibacterium salmoninarum gen. nov., sp. nov., the causative agent of bacterial kidney disease in salmonid fishes. Int. J. syst. Bacteriol. 30: 496-502

Wooten, R., McVicar, A.H. (1982). Dermocystidium from cultured eels, Anguilla anguilla L, in Scotjand. J. Fish Dis. 5: $215-222$

Manuscript first received: June 5, 1989

Revised version accepted: August 23, 1989 